Jurnal Ilmu Ilmu Agribisnis: Journal of Agribusiness Science, 9(1), Februari 2021

\title{
ANALISIS EFISIENSI USAHATANI JAGUNG ANGGOTA DAN NON-ANGGOTA KELOMPOK TANI DI KECAMATAN MARGA TIGA KABUPATEN LAMPUNG TIMUR
}

\author{
(Corn Farming Efficiency Analysis of Members and Nonmembers of Farmer Groups in \\ Marga Tiga District East Lampung Regency)
}

Ni Nyoman Tri Santiasih, Dyah Aring Hepiana Lestari, Ani Suryani

\begin{abstract}
Jurusan Agribisnis, Fakultas Pertanian, Universitas Lampung, Jl. Prof. Dr. Soemantri Brojonegoro No.1
Bandar Lampung, 35145,e-mail: dyah.aring@fp.unila.ac.id
\end{abstract}

\begin{abstract}
This research aims to analyze the level of technical efficiency, technical inefficiency factors, and economic efficiency of corn farming of members and nonmembers of farmer groups. This research was conducted in the Gedung Wani and Negeri Katon Villages of Marga Tiga District, East Lampung. Respondent farmers were determined intentionally with a simple random sampling. This research use a survey method and the data were collected in February-March 2019. Technical efficiency, technical inefficiency factors, and economic efficiency were analyzed using the Stochastic Frontier 4.1. The results showed that corn farming in Marga Tiga District was technically efficient, with an efficiency of 0.95. The number of family members can increase technical inefficiency, age and experience can reduce technical inefficiency, while education and farmer groups membership do not affect technical inefficiency. Corn farming in Marga Tiga District was also economically efficient with an efficiency level 0.89 for members of farmer groups and 0.90 for nonmembers of farmer groups.
\end{abstract}

Keywords: corn farming, efficiency, farmer groups

\section{PENDAHULUAN}

Pertanian merupakan sektor yang paling penting dalam kehidupan manusia, dimana segala kebutuhan manusia bersumber dari hasil pertanian baik pangan, papan, maupun sandang. Perkembangan teknologi yang semakin pesat di era moderen ini pun belum mampu mengganti peran hasil pertanian sebagai pemenuhan dasar kebutuhan manusia. Bahkan pertanian menjadi sumber pendapatan bagi banyak negara seperti Jepang, Belanda, Amerika Serikat, Australia, China, termasuk Indonesia (Edwin 2015).

Pertanian di Indonesia memiliki andil yang besar dalam pertumbuhan ekonomi nasional. Komoditi pertanian mampu berkontribusi sebesar 1,75 persen dari keseluruhan ekspor yang dilakukan Indonesia pada tahun 2018. Meskipun persentase ini lebih rendah dari tahun 2017 yaitu sebesar 2,09 persen, tetapi terdapat peningkatan beberapa jumlah komoditi pertanian yang diekspor. Komoditi pertanian yang paling banyak diekspor adalah tanaman pangan, sebesar 128.926 ribu ton $(12,96 \%)$ dari keseluruhan jumlah komoditi pertanian yang diekspor sebesar 994.800 ribu ton. Komoditi pangan yang terus diekspor dan mengalami peningkatan yang signifikan adalah jagung. Peningkatan ekspor jagung terjadi pada tahun 2017-2018 dari yang sebelumnya hanya 542.000 ton menjadi 45.622 .400 ton. Jumlah ekspor yang meningkat menunjukkan terjadinya peningkatan produksi jagung nasional. Peningkatan produksi jagung ini tidak lepas dari upaya pemerintah untuk terus mendorong produksi pangan terutama komoditas-komoditas yang strategis (BPS 2018).

Jagung yang diekspor berasal dari beberapa provinsi, salah satunya Provinsi Lampung. Provinsi Lampung menduduki peringkat ke-tiga sebagai sentra produksi jagung. Produksi di Provinsi Lampung berasal dari 15 kabupaten/kota, dimana Kabupaten Lampung Timur menjadi penghasil terbesar pada tahun 2017 dengan jumlah produksi 735.743 ton. Produksi di Kabupaten Lampung Timur berasal dari 24 kecamatan dan kecamatan yang memiliki luas panen yang cukup tinggi yaitu 7.112 ha, namun produktivitasnya masih tergolong rendah (5,32 ton/ha) adalah Kecamatan Marga Tiga. Produktivitas jagung di Kecamatan Marga Tiga masih tergolong rendah jika dibandingkan dengan kecamatan yang memiliki luas panen lebih rendah seperti Kecamatan Batang Hari dengan luas panen 3.435 ha, namun produktivitasnya dapat mencapai 5,82 ton/ha (BPS Provinsi Lampung 2018). 
Kecamatan Marga Tiga terdiri dari 13 desa. Desa Gedung Wani dan Negeri Katon memiliki produktivitas yang paling rendah. Namun, justru kedua desa ini memiliki jumlah kelompok tanitertinggi yaitu 51 dan 44 kelompok tani dengan jumlah anggota 728 dan 730 orang (BPS Kabupaten Lampung Timur 2018 ). Produktivitas yang rendah menunjukkan adanya permasalahan dalam usahatani jagung yang dilakukan. Permasalahan tersebut antara lain kurang efisiennya penggunaan faktor produksi dan kurangnya kemampuan manajerial yang dimiliki petani. Kemampuan manajerial dapat diperoleh petani melalui keikutsertaanya dalam kelompok tani. Peningkatan kemampuan manajerial diharapkan mampu meningkatkan efisiensi usahatani (Nuryanti dan Swastika 2011).

Petani masih enggan untuk bergabung dalam kelompok tani. Hal ini terlihat dari total jumlah petani di Kecamatan Marga Tiga pada tahun 2017 adalah 9.991 orang, hanya sebanyak 6.580 orang tergabung dalam kelompok tani. Meskipun banyak keuntungan yang diperoleh, petani masih enggan untuk bergabung dalam kelompok tani, karena mereka menganggap bahwa bergabung dalam kelompok tani akan menganggu waktu dan tidak akan memberikan dampak pada pendapatan serta kegiatan usahatani mereka. Berdasarkan uraian sebelumnya, maka tujuan yang hendak dianalisis dalam penelitian ini adalah tingkat efisiensi teknis, faktor-faktor yang mempengaruhi inefisiensi teknis dan efisiensi ekonomi usahatani jagung anggota dan non-anggota kelompok tani di Kecamatan Marga Tiga Kabupaten Lampung Timur.

\section{METODE PENELITIAN}

Penelitian ini menggunakan metode survei. Populasi yang akan diteliti adalah petani jagung anggota kelompok tani dan non-anggota kelompok tani di Desa Gedung Wani dan Negeri Katon Kecamatan Marga Tiga. Kedua desa ini dipilih secara purposive dengan pertimbangan kedua desa tersebut merupakan desa dengan produktivitas jagung yang rendah dan memiliki kelompok tani terbanyak. Desa Gedung Wani terdiri dari 51 kelompok tani dengan anggota 728 orang, sedangkan Desa Negeri Katon terdiri dari 44 kelompok tani dengan jumlah anggota 730 orang. Jumlah petani jagung Desa Gedung Wani 821 orang dan Desa Negeri Katon 884 orang, sehingga jumlah petani yang tidak ikut dalam kelompok tani di kedua desa berturut-turut adalah 93 dan 154 orang (BPP Kecamatan Marga Tiga 2018).
Metode pengambilan sampel dilakukan dengan menggunakan metode acak sederhana (simple random sampling). Jumlah sampel anggota dan non-anggota kelompok tani dihitung dengan rumus Isaac dan Michael dalam Ismail (2018), dengan penulisan rumus sebagai berikut:

$$
s=\frac{\chi^{2} N \text { P Q }}{d^{2}(N-1)+\chi^{2} P Q}
$$

\section{Keterangan:}

$\begin{array}{ll}\mathrm{S} & \text { : Jumlah sampel } \\ \chi^{2} & \text { : Kai kuadrat untuk kesalahan 10\% }(1,65) \\ \mathrm{N} & \text { : Jumlah populasi 1.458 (anggota } \\ & \text { kelompok tani) dan 274 (non-anggota } \\ & \text { kelompok tani), diperoleh dari } \\ & \text { penjumlahan antara petani jagung Desa } \\ & \text { Gedung Wani dengan jumlah petani } \\ & \text { jagung Desa Negeri Katon (orang) } \\ & \text { : Peluang benar }(0,50) \\ \mathrm{Q} & \text { : Peluang salah }(0,50) \\ \mathrm{d} & \text { : Derajat penyimpangan }(10 \%)\end{array}$

Berdasarkan perhitungan, diperoleh jumlah sampel anggota kelompok tani 65 orang dan sampel nonanggota kelompok tani sebanyak 53 orang. Setelah diperoleh sampel anggota dan non-anggota kelompok tani, sampel ditentukan secara proporsional masing-masing desa dengan rumus:

$\mathrm{na}=\frac{\mathrm{Na}}{\mathrm{Nab}} \cdot \mathrm{nab}$

Keterangan:

na : Jumlah sampel anggota/non-kelompok tani

nab : Jumlah sampel kelompok/non-kelompok tani keseluruhan (orang)

na : Jumlah populasi kelompok/non-kelompok tani (orang)

nab : Jumlah populasi keseluruhan anggota/ non anggota kelompok tani (orang)

Berdasarkan alokasi proporsional diperoleh sampel Desa Gedung Wani sebanyak 33 anggota dan 20 non-anggota kelompok tani, sedangkan Desa Negeri Katon diperoleh sampel sebanyak 32 anggota dan 33 non-anggota kelompok tani.

Data yang dikumpulkan adalah data primer dan data sekunder. Pengambilan data dilakukan pada bulan Februari- Maret 2019. Metode analisis data yang digunakan adalah analisis deskriptif kuantitatif. Tujuan pertama dianalisis dengan menggunakan fungsi produksi stochastic frontier, sedangkan tujuan kedua dianalisis dengan fungsi 
biaya dual frontier dengan cara meminimumkan biaya input dengan kendala fungsi produksi stockhastik frontier (Kurniawan 2010).

Fungsi produksi stochastic frontier digunakan untuk mengetahui tingkat efisiensi dan faktorfaktor yang mempengaruhi inefisiensi usahatani jagung anggota dan non-anggota kelompok tani di Kecamatan Marga Tiga. Secara matematis, model persamaan penduga fungsi produksi stochastic frontier pada usahatani jagung anggota dan nonanggota kelompok tani dapat dituliskan sebagai berikut :

$\operatorname{LnYi}=\ln \beta_{0}+\sum_{\mathrm{i}=1}^{7} \beta_{\mathrm{i}} \ln \mathrm{X}_{\mathrm{i}}+\mathrm{v}_{\mathrm{i}}-\mathrm{u}_{\mathrm{i}}$

Keterangan :

Yi $\quad$ : Total produksi jagung $(\mathrm{kg})$

$\beta_{0} \quad$ : Intersep

$\beta_{\mathrm{i}} \quad$ : Elastisitas produksi ke-i

$\mathrm{X}_{1}$ : Luas lahan garapan usahatani jagung (ha)

$\mathrm{X}_{2} \quad$ : Penggunaan benih $(\mathrm{kg})$

$\mathrm{X}_{3} \quad$ : Penggunaan pupuk urea $(\mathrm{kg})$

$\mathrm{X}_{4} \quad$ : Penggunaan pupuk SP36 $(\mathrm{kg})$

$\mathrm{X}_{5} \quad$ : Penggunaan pupuk NPK $(\mathrm{kg})$

$\mathrm{X}_{6} \quad$ : Penggunaan pupuk Organik $(\mathrm{kg})$

$\mathrm{X}_{7}$ : Penggunaan tenaga kerja (HKP)

vi-ui : Error term

Besarnya efisiensi teknis petani jagung ke-i dapat dihitung dengan formulasi sebagai berikut:

$\mathrm{ET}=\frac{\mathrm{Y}_{\mathrm{i}}}{\widehat{\mathrm{Y}}_{\mathrm{i}}}$

Keterangan :

ET : Tingkat efisiensi teknis produksi

$\mathrm{Y}_{\mathrm{i}} \quad$ : Produksi aktual ke-i

$\widehat{\mathrm{Y}}_{\mathrm{i}} \quad$ : Produksi potensial/frontier ke-i

Efisiensi teknis untuk seorang petani berkisar antara $0 \leq \mathrm{ET} \leq 1$. Nilai efisiensi teknis petani dikategorikan sangat efisien jika bernilai $>0,90$, cukup efisien jika bernilai $0,70 \leq \mathrm{ET} \leq 0,90$ dan kategori belum efisien jika bernilai < 0,70 (Coeli dan Battese 1998).Terdapat kemungkinan tidak tercapainya efisiensi teknis pada usahatani jagung anggota dan non-anggota kelompok tani, sehingga perlu dianalisis faktor-faktor yang mempengaruhi inefisiensi teknis dengan rumus:

$\mathrm{Ui}=\delta 0+\delta_{1 \mathrm{z} 1}+\delta_{2 \mathrm{Z2}}+\delta_{3 \mathrm{Z3}}+\delta_{4 \mathrm{Z} 4}+\delta_{5 \mathrm{Z} 5}$

Keterangan :

Ui : Inefisiensi teknis

$\delta \quad:$ Koefisien

Z1 : Umur petani (tahun)

132
Z2 : Pendidikan formal (tahun)

Z3 : Jumlah anggota keluarga (orang)

Z4 : Pengalaman (tahun)

Z5 : Dummy kelompok tani ( $1=$ anggota KT dan $0=$ non-anggota KT)

Pengukuran efisiensi ekonomi dapat dilakukan dengan menurunkan fungsi biaya dual dari fungsi produksi Cobb-Douglas yang homogen. Efisiensi ekonomi ditentukan berdasarkan rasio total biaya produksi minimum (Ci) dengan total biaya produksi aktual atau biaya produksi total $\left(\mathrm{Ci}^{*}\right)$, sehingga persamaan menjadi :

$\mathrm{EE}=\frac{\mathrm{C}_{\mathrm{i}}}{\mathrm{C}_{\mathrm{i}}^{*}}$

Keterangan:

$\mathrm{C}_{\mathrm{i}} \quad$ : Total biaya produksi minimum yang diobservasi

$\mathrm{C}_{\mathrm{i}}^{*} \quad$ : Total biaya aktual secara keseluruhan

Persamaan biaya produksi minimum dapat dituliskan secara matematis sebagai berikut:

$\mathrm{C}_{\mathrm{i}}=\mathrm{f}\left(\mathrm{Y}, \mathrm{P}_{1}, \mathrm{P}_{2}, \mathrm{P}_{3}, \mathrm{P}_{4}, \mathrm{P}_{5}, \mathrm{P}_{6}, \mathrm{P}_{7}\right)+\mathrm{ei}$

Keterangan:

C : Biaya produksi jagung

$\mathrm{Y} \quad$ : Hasil produksi jagung

$\mathrm{P}_{1} \quad$ : Harga sewa lahan $(\mathrm{Rp} / \mathrm{kg})$

$\mathrm{P}_{2} \quad$ : Harga benih $(\mathrm{Rp} / \mathrm{kg})$

$\mathrm{P}_{3} \quad$ : Harga pupuk urea $(\mathrm{Rp} / \mathrm{kg})$

$\mathrm{P}_{4} \quad$ : Harga pupuk SP36 $(\mathrm{Rp} / \mathrm{kg})$

$\mathrm{P}_{5} \quad$ : Harga pupuk NPK $(\mathrm{Rp} / \mathrm{kg})$

$\mathrm{P}_{6} \quad$ : Harga pupuk organik $(\mathrm{Rp} / \mathrm{kg})$

$\mathrm{P}_{7} \quad$ : Upah tenaga kerja (Rp/HKP)

Menurut Ogundari dan Ojo (2006) dalam Kurniawan (2010), dengan menggunakan program komputer Frontier 4.1, maka nilai Cost Efficiency (CE) dihitung dari invers persamaan biaya stockastik frontier, sedangkan efisiensi ekonomi merupakan 1/CE. Kriteria pengambilan keputusan tingkat efisiensi adalah kategori sangat efisien jika bernilai $\geq 0,90$, cukup efisien jika bernilai 0,70 0,90 dan belum efisien jika bernilai $<0,70$.

\section{HASIL DAN PEMBAHASAN}

\section{Kelompok Tani}

Kelompok tani di Kecamatan Marga Tiga merupakan kelompok tani dengan klasifikasi pemula, karena rata-rata terbentuk $<5$ tahun. Jumlah anggota dalam setiap kelompok tani berkisar antara 20-30 orang yang terdiri dari ketua, 
sekretaris, bendahara, dan anggota. Beberapa kelompok tani responden di Desa Gedung Wani dan Negeri Katon antara lain Tani Baru 1, Tani Baru 2, Rahayu 4, Rahayu 3, Makmur Jaya, Ngudi Makmur 4, Sumber Batu dan Tunas Remaja. Kegiatan yang dilakukan oleh kelompok tani responden di daerah penelitian yaitu rapat dan pertemuan untuk pembagian bantuan. Rapat dilakukan setiap tiga bulan sekali, tanpa pendampingan, hanya dilakukan untuk membicarakan bantuan dan pembayaran uang kas tanpa diskusi mengenai usahatani jagung. Kelompok tani di Kecamatan Marga Tiga pun belum pernah menerima pelatihan mengenai usahatani jagung. Kelompok tani sudah mendapat perhatian dengan adanya bantuan subsidi sarana produksi seperti pupuk dan benih, namun ketersediaanya belum mencukupi kebutuhan petani, sehingga petani anggota masih harus tetap membeli sarana produksi di kios-kios sekitar meskipun harganya lebih mahal.

\section{Karakteristik Responden}

Mayoritas umur petani jagung anggota kelompok tani adalah kelompok umur 37-45 tahun, sedangkan non-anggota kelompok tani didominasi oleh kelompok umur 55-63 tahun. Rata-rata umur petani anggota maupun non-anggota kelompok tani sama yaitu 52 tahun. Hal ini berarti bahwa sektor pertanian khususnya jagung di Kecamatan Marga Tiga kurang diminati oleh petani usia muda (20-40 tahun). Rata-rata tingkat pendidikan petani anggota kelompok tani sudah tergolong tinggi yaitu tamatan SMA 49,23 persen, tamat SMP 18,46 persen, tamat SD 30,77 persen, dan tamat S1 hanya 1,54 persen. Hal serupa juga dijumpai pada petani jagung non-anggota kelompok tani, dimana tamatan SMA sebanyak 39,62 persen, tamat SMP 16,98 persen, tamat SD 39,62 persen, dan 3,77 persen tamatan $\mathrm{S} 1$.

Jumlah anggota keluarga petani anggota maupun non-anggota tidak jauh berbeda, didominasi oleh petani dengan jumlah anggota keluarga 3-5 orang. Petani anggota sebanyak 76,92 persen dan nonanggota sebanyak 75,47 persen jumlah anggota keluarga 3-5 orang. Pengalaman usahatani jagung petani di Kecamatan Marga Tiga rata-rata 20-28 tahun baik petani anggota maupun non-anggota kelompok tani. Pengalaman yang dimiliki oleh petani dapat dijadikan sebagai peluang meningkatkan efisiensi dalam penggunaan input produksi.
Petani anggota kelompok tani belum pernah menerima pelatihan yang berkaitan dengan usahatani jagung. Rapat masih dilakukan paling sering 3 bulan sekali yang dilakukan oleh sekitar 66,15 persen petani responden. Selain keanggotaan dalam kelompok tani, penguasaan lahan pun akan mempengaruhi petani dalam melakukan usahatani jagung. Sebanyak 66,15 persen petani anggota kelompok tani mengelola lahan jagung seluas $0-1$ ha, dan sisanya 32,85 persen lebih dari 1ha. Petani non-anggota kelompok tani sebanyak 92,45 persen mengelola lahan jagung 0-1 ha dan sisanya 7,55 persen penguasaan lahannya lebih dari 1ha. Status kepemilikan lahan petani jagung anggota kelompok tani 81,53 persen merupakan milik sendiri, sedangkan petani non-anggota kelompok tani mencapai 92,45 persen petani status kepemilikannya merupakan milik sendiri. Penyusutan sarana produksi pun hanya dihitung satu musim tanam saja, dengan asumsi bahwa semua peralatan pertanian hanya digunakan untuk usahatani jagung saja. Jenis peralatan pertanian yang digunakan antara lain cangkul, arit, golok, dan sprayer. Biaya penyusutan sarana produksi anggota kelompok tani Rp36.138,90/musim tanam, sedangkan non-kelompok tani hanya sekitar Rp32.775,47/musim tanam.

Analisis efisiensi usahatani jagung dilakukan pada satu musim tanam yaitu musim tanam I yang dimulai pada akhir bulan September atau Oktober hingga akhir Januari. Pada musim tanam I, seluruh petani jagung di Kecamatan Marga Tiga melakukan penanaman, karena sudah memasuki musim penghujan dan curah hujan belum terlalu tinggi, sehingga hama penyakit dan biaya perawatan rendah. Penanaman yang dilakukan lebih awal biasanya memiliki nilai jual tinggi, karena belum semua petani berani melakukan penanaman saat curah hujan masih sangat rendah.

Sumber permodalan baik petani anggota maupun non-anggota menggunakan modal sendiri, pengalokasian modal tertinggi untuk pembelian pupuk dan benih. Penggunaan saprodi di lokasi penelitian masih belum mengacu pada anjuran pemerintah seperti pupuk urea, NPK, dan SP36 yang penggunaannya lebih dari anjuran, sedangkan pupuk oraganik penggunaannya masih kurang dari anjuran. Hasil penelitian menunjukkan produksi rata-rata petani jagung anggota $5.702,98 \mathrm{~kg} / \mathrm{ha}$ dan petani non-anggota kelompok tani mencapai $5.392,72 \mathrm{~kg} / \mathrm{ha}$. Hasil ini masih kurang dari produksi yang seharusnya dihasilkan per ha jagung 
hibrida yaitu mencapai $10-12$ ton bonggolan atau 5-6 ton jagung pipilan kering.

\section{Efisiensi Teknis Usahatani Jagung}

Hasil analisis efisiensi teknis usahatani jagung anggota dan non-anggota di Kecamatan Marga Tiga ditampilkan pada Tabel 1. Efisiensi teknis dianalisis dengan fungsi produksi Stochastic Frontier dengan aplikasi frontier 4.1. Efisiensi teknis mencerminkan keterampilan petani dalam mengatur penggunaan input produksi secara optimal.

Nilai sigma-square dan gamma yang diperoleh dari pendugaan MLE sebesar 0,048 dan 0,101 dengan tingkat kepercayaan 99 persen. Nilai gamma lebih dari nol menunjukkan bahwa terdapat pengaruh inefisiensi teknis pada model. Nilai sigma-square menunjukkan bahwa variasi nilai komposit error disebabkan oleh inefisiensi teknis. Berdasarkan Tabel 1, nilai sigma-square sebesar 0,048 menunjukan bahwa variasi nilai kesalahan disebabkan oleh komponen inefisiensi teknis sebesar 4,80 persen. Hasil ini berarti bahwa perbedaan yang terjadi antara produksi yang sebenarnya dengan produksi maksimum lebih banyak disebabkan oleh efek inefisiensi teknis dan bukan disebabkan oleh faktor error lain yang tidak termasuk dalam model.

Tabel 1. Hasil pendugaan fungsi produksi stochastic frontier usahatani jagung anggota dan non-anggota kelompok tani di Kecamatan Marga Tiga tahun 2019

\begin{tabular}{llcc}
\hline \multicolumn{1}{c}{ Variabel } & Coefficient & $\begin{array}{c}\text { Standard } \\
\text { Error }\end{array}$ & t-ratio \\
\hline Intersep & $6,669 * * *$ & 0,973 & 6,852 \\
Lahan (X1) & $0,423 *$ & 0,246 & 1,720 \\
Benih (X2) & $0,352^{* * *}$ & 0,141 & 2,494 \\
Pupuk urea (X3) & 0,057 & 0,714 & 0,081 \\
Pupuk SP36 (X4) & 0,187 & 0,463 & 0,405 \\
Pupuk NPK (X5) & $-0,110^{* * *}$ & 0,063 & $-1,747$ \\
Pupuk organik (X6) & $-0,159 * * *$ & 0,057 & $-2,759$ \\
Tenaga kerja (X7) & 0,292 & 0,502 & 0,582 \\
Sigma-squared & $0,048 * * *$ & 0,005 & 9,534 \\
Gamma & $0,101 * * *$ & 0,020 & 4,931 \\
\hline Log likelihood & 16,811 & &
\end{tabular}

\begin{tabular}{ll}
\hline Log likelihood OLS & 16,811 \\
Log likelihood MLE & 27,796 \\
LR-test & 21,969 \\
\hline Keterangan: & \\
$*$ & $:$ Tingkat kepercayaan $90 \%(\mathrm{t}$-tabel $=1,26897)$ \\
$* *$ & Tingkat kepercayaan $95 \%(\mathrm{t}$-tabel $=1,98177)$ \\
$* * * \quad:$ Tingkat kepercayaan $99 \%(\mathrm{t}$-tabel $=2,36170)$
\end{tabular}

Tabel 2. Sebaran efisiensi teknis usahatani jagung anggota dan non-anggota kelompok tani di Kecamatan Marga Tiga tahun 2019.

\begin{tabular}{|c|c|c|c|c|c|}
\hline \multirow{2}{*}{$\begin{array}{l}\text { Efisiensi } \\
\text { Teknis }\end{array}$} & \multicolumn{2}{|c|}{ Anggota KT } & \multicolumn{2}{|c|}{ Non-Anggota KT } & \multirow[b]{2}{*}{ Ket } \\
\hline & $\begin{array}{c}\text { Jumlah } \\
\text { (Org) }\end{array}$ & $\begin{array}{c}\text { Persen } \\
(\%)\end{array}$ & $\begin{array}{c}\text { Jumlah } \\
\text { (Org) }\end{array}$ & $\begin{array}{c}\text { Persen } \\
(\%)\end{array}$ & \\
\hline$<0,70$ & 0,00 & 0,00 & 0,00 & 0,00 & $\begin{array}{l}\text { Belum } \\
\text { efisien }\end{array}$ \\
\hline $0,70-90$ & 10,00 & 15,38 & 1,00 & 1,89 & $\begin{array}{l}\text { Cukup } \\
\text { Efisien }\end{array}$ \\
\hline$>90$ & 55,00 & 84,62 & 52,00 & 98,11 & $\begin{array}{l}\text { Sangat } \\
\text { Efisien }\end{array}$ \\
\hline Jumlah & 65,00 & 100,00 & 53,00 & 100,00 & \\
\hline Rata-rata & 0,95 & & 0,95 & & \\
\hline Min & 0,75 & & 0,79 & & \\
\hline Maks & 1,00 & & 0,99 & & \\
\hline
\end{tabular}

Tabel 1 menunjukkan bahwa benih, pupuk NPK, dan pupuk organik berpengaruh nyata terhadap produksi pada tingkat kepercayaan 99 persen, sedangkan luas lahan berpengaruh nyata pada tingkat kepercayaan 90 persen. Hal ini berarti bahwa, jika terjadi penambahan luas lahan, benih, pupuk NPK, dan pupuk organik sebesar 1 persen, maka akan menambah produksi sebesar nilai koefisien frontier tersebut. Fungsi produksi stockhastic frontier dapat pula digunakan untuk mengetahui tingkat efisiensi teknis melalui pendekatan output.

Tabel 2 menunjukkan bahwa mayoritas petani jagung anggota kelompok tani sudah efisien secara teknis, karena dari 65 petani responden sebanyak 55 petani $(84,62 \%)$ dikategorikan sangat efisien dan 10 petani $(15,38 \%)$ dikategorikan cukup efisien. Petani non-anggota kelompok juga telah mencapai efisiensi teknis, dimana dari 53 petani responden sebanyak 52 petani $(98,11 \%$ ) sudah sangat efisien secara teknis dan 1 petani $(1,89 \%)$ dikategorikan sudah cukup efisien.

Jumlah petani yang mencapai kategori efisien secara teknis antara petani anggota dan nonanggota kelompok tani tidak memiliki perbedaan yang signifikan. Hanya terdapat perbedaan sekitar 13,50 persen. Hal ini terjadi karena faktor produksi dan teknik usahatani yang digunakan petani anggota dan non-anggota kelompok tani relatif sama. Rata-rata tingkat efisiensi teknis usahatani jagung baik anggota maupun nonanggota kelompok tani mencapai 0,95 yang artinya sudah sangat efisien secara teknis. Rata-rata tingkat efisiensi juga menunjukkan bahwa petani telah mencapai 95,00 persen dari potensial produksinya dan masih ada sekitar 5,00 persen peluang untuk meningkatkan produksinya. 
Tingkat efisiensi teknis dapat diartikan berwajah ganda, disatu sisi tingkat efisiensi teknis yang tinggi mencerminkan pencapaian petani yang telah mampu mengatur usahataninya. Di sisi lain, efisiensi yang tinggi artinya peluang kecil untuk meningkatkan produktivitasnya, karena kesenjangan antara produktivitas yang telah dicapai dengan produktivitas maksimumnya sangat sempit. Hasil ini sejalan dengan penelitian Noer, Zakaria, dan Murniati (2018), semakin tinggi tingkat efisiensi teknis usahatani, maka kemampuan petani untuk mengelola usahataninya semakin baik, namun semakin kecil peluang petani untuk meningkatkan produktivitasnya.

\section{Faktor-faktor Inefisiensi Teknis Usahatani Jagung}

Inefisiensi teknis dianalisis dengan fungsi produksi stochastic frontier. Hasil regresi menunjukkan peluang efisiensi teknis sebesar 5 persen yang belum tercapai diakibatkan oleh pengaruh faktor eksternal dan internal. Faktor-faktor yang digunakan sebagai penduga inefisiensi teknis yaitu umur, pendidikan, jumlah anggota keluarga, pengalaman, dan keanggotaan dalam kelompok tani. Hasil regresi dapat dituliskan dalam persamaan berikut :

$$
\begin{aligned}
\mathrm{Ui}= & 6,6695-0,2828 \ln Z_{1}+0,2292 \ln Z_{2}+0,5329 \\
& \ln Z_{3}-0,1278 \ln Z_{4}+0,0528 \ln Z_{5}
\end{aligned}
$$

Berdasarkan Tabel 3, penjelasan masing-masing faktor yang mempengaruhi inefisiensi teknis anggota dan non-anggota kelompok tani di Kecamatan Marga Tiga adalah sebagai berikut :

1. Umur petani $\left(\mathrm{Z}_{1}\right)$

Variabel umur berpengaruh nyata terhadap inefisiensi teknis dengan nilai koefisien sebesar -0,2828. Nilai tersebut berarti bahwa jika umur petani bertambah 1 persen, maka akan menurunkan inefisiensi teknissebesar 0,2828 persen. Hal ini tidak sejalan dengan penelitian Putri, Murdani, dan Fadli (2015) yang menyatakan bahwa semakin bertambahnya umur petani, maka semakin meningkatkan inefisiensi teknis.

2. Pendidikan $\left(\mathrm{Z}_{2}\right)$

Variabel pendidikan tidak berpengaruh nyata terhadap inefisiensi teknis, namun pendidikan memiliki kecenderungan berkolerasi positif terhadap inefisiensi. Hal ini berarti semakin tinggi tingkat pendidikan, maka akan meningkatkan inefisiensi teknis.
Tabel 3. Parameter faktor-faktor inefisiensi teknis petani jagung anggota dan non-anggota kelompok tani di Kecamatan Marga Tiga tahun 2019

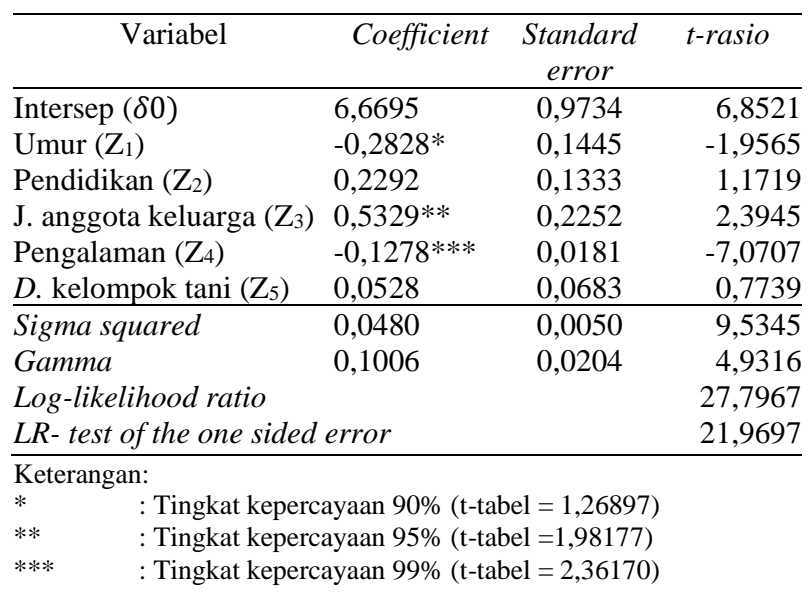

Pendidikan justru dapat membuat petani menerapkan teknik budidaya yang belum tentu sesuai dengan kondisi lingkungan usahatani, sehingga terdapat kecenderungan meningkatkan inefisiensi teknis. Hasil ini tidak sejalan dengan penelitian Rofiqoh, Agustina, dan Hartadi (2018) bahwa pendidikan petani memiliki nilai yang berkolerasi negatif dan tidak berpengaruh nyata terhadap inefisiensi teknis.

3. Jumlah anggota keluarga $\left(\mathrm{Z}_{3}\right)$

Variabel jumlah anggota keluarga petani juga berpengaruh nyata dan berkolerasi positif terhadap inefisiensi teknis dengan nilai koefisien 0,5329. Semakin bertambahnya anggota keluarga akan meningkatkan alokasi modal untuk memenuhi kebutuhan sehari-hari dan biaya sekolah, sehingga alokasi modal untuk usahatani berkurang. Hal ini menyebabkan penggunaan faktor produksi kurang optimal dan dapat meningkatkan inefisiensi teknis. Hasil ini sejalan dengan penelitian Muhaimin (2012) yang menyatakan bahwa jumlah anggota keluarga berpengaruh nyata dan berkolerasi positif terhadap inefisiensi.

4. Pengalaman $\left(\mathrm{Z}_{4}\right)$.

Variabel pengalaman berpengaruh nyata dan berkolerasi negatif terhadap inefisiensi teknis dengan koefisien 0,1278 . Jika pengalaman usahatani jagung bertambah 1 persen, maka akan menurunkan inefisiensi teknis sebesar 0,1278 persen. Petani di daerah penelitian melakukan usahatani berdasarkan kebiasaan dan pengetahuan turun-temurun, sehingga semakin lama pengalaman usahatani, maka semakin mengetahui cara yang tepat untuk 
mengatasi masalah dalam usahatani jagung. Hasil ini sejalan dengan penelitian Putri et al. (2015) yang menyatakan pengalaman petani akan menurunkan inefisiensi teknis.

5. Dummy kelompok tani $\left(\mathrm{Z}_{5}\right)$

Variabel kelompok tani tidak berpengaruh nyata, tetapi berkolerasi positif terhadap inefisiensi teknis usahatani jagung. Hasil ini menujukkan tingkat efisiensi teknis usahatani jagung anggota dan non-anggota kelompok tani sama. Hal ini dikarenakan kelompok tani hanya digunakan sebagai wadah untuk menerima bantuan, namun bantuan yang diterima belum dapat memenuhi kebutuhan usahatani jagung yang dilakukan petani, sehingga petani anggota kelompok tani harus tetap membeli faktor produksi di kios-kios terdekat seperti yang dilakukan petani non-anggota kelompok tani.

\section{Efisiensi Ekonomi Usahatani Jagung}

Efisiensi ekonomi dianalisis menggunakan fungsi biaya produksi stochastic frontier, dengan software frontier 4.1. Parameter yang digunakan pada model ini diestimasi dengan metode Maximum Likelihood Estimated (MLE). Hasil pendugaan fungsi biaya produksi stochastic frontier usahatani jagung anggota dan non-anggota kelompok tani di Kecamatan Marga Tiga disajikan pada Tabel 4.

Model fungsi biaya usahatani jagung menunjukkan nilai log likelihood MLE $(0,879)$ lebih besar dari nilai log likelihood OLS $(0,842)$ yang berarti fungsi dengan metode MLE lebih baik dan sesuai dengan kondisi di daerah penelitian. Efisiensi ekonomi diperoleh melalui analisis dari sisi input produksi menggunakan biaya input yang berlaku di tingkat petani.

Berdasarkan Tabel 4, terlihat bahwa koefisien regresi harga sewa lahan (P1), harga benih (P2), harga urea (P3), harga NPK (P5), upah tenaga kerja (P7) berpengaruh nyata pada tingkat kepercayaan 99 persen, koefisien harga pupuk organik (P6) dan harga pupuk SP36 (P4) berpengaruh nyata pada tingkat kepercayaan 95 persen. Variabel yang digunakan adalah harga tertimbang (biaya input/output). Hasil ini menunjukkan bahwa petani di Kecamatan Marga Tiga baik anggota dan non-anggota kelompok tani telah mampu mengalokasi-kan input dengan biaya minimum untuk memperoleh output marjinal yang diinginkan.
Tabel 4. Hasil pendugaan fungsi biaya produksi stochastic frontier usahatani jagung anggota dan non-anggota kelompok tani di Kecamatan Marga Tiga tahun 2019

\begin{tabular}{|c|c|c|c|}
\hline Variabel & Coefficient & $\begin{array}{c}\text { Standarder } \\
\text { ror }\end{array}$ & t-ratio \\
\hline Intersep & $10,919 * * *$ & 0,101 & 108,560 \\
\hline Harga sewa lahan (P1) & $0,366 * * *$ & 0,041 & 8,856 \\
\hline Harga benih (P2) & $0,060 * * *$ & 0,018 & 3,202 \\
\hline Harga urea (P3) & $0,113 * * *$ & 0,044 & 2,575 \\
\hline Harga SP36 (P4) & $0,079 * *$ & 0,039 & 2,016 \\
\hline Harga NPK (P5) & $0,212 * * *$ & 0,035 & 6,047 \\
\hline Harga pupuk organik (P6) & $0,040 * *$ & 0,020 & 2,007 \\
\hline Upah tenaga kerja (P7) & $0,039 * * *$ & 0,010 & 3,869 \\
\hline Sigma-squared & $0,027 * * *$ & 0,006 & 4,194 \\
\hline Gamma & $0,769 * * *$ & 0,128 & 6,006 \\
\hline Log likelihood OLS & 0,842 & & \\
\hline Log likelihood MLE & 0,879 & & \\
\hline LR-test & 0,747 & & \\
\hline \multicolumn{4}{|c|}{ Keterangan: } \\
\hline \multicolumn{4}{|c|}{ : Tingkat kepercayaan 90\% $(\mathrm{t}$-tabel $=1,65882)$} \\
\hline \multicolumn{4}{|c|}{ : Tingkat kepercayaan $95 \%(\mathrm{t}-\mathrm{tabel}=1,98177)$} \\
\hline \multicolumn{4}{|c|}{ : Tingkat kepercayaan 99\% (t-tabel $=2,62129)$} \\
\hline
\end{tabular}

Nilai efisiensi ekonomi per individu usahatani diperoleh dari satu dibagi dengan nilai efisiensi biaya. Efisiensi ekonomi merupakan efek gabungan dari efisiensi teknis dan efisiensi alokatif, sehingga usahatani dikatakan efisien secara ekonomis jika efisiensi teknis dan alokatif tercapai. Sebaran tingkat efisiensi ekonomi usahatani jagung anggota dan non-anggota kelompok tani di Kecamatan Marga Tiga disajikan pada Tabel 5.

Petani non-anggota kelompok tani memiliki ratarata tingkat efisiensi lebih tinggi. Seluruh responden sudah mencapai efisiensi ekonomi dimana 26,42 persen petani cukup efisien dan 73,58 persen petani sangat efisien. Petani anggota kelompok tani justru sebaliknya, masih terdapat petani jagung yang belum efisien secara ekonomi sebanyak 3,08 persen. Tidak tercapainya efisiensi ekonomi ini disebabkan oleh penggunaan faktor produksi yang berlebihan.

Pencapaian tingkat efisiensi ekonomi rata-rata anggota kelompok tani 0,89 dan non-anggota kelompok tani 0,90 . Hal ini menunjukkan petani berada pada kategori cukup efisien dan menguntungkan secara ekonomi. Hasil ini tidak sejalan dengan penelitian Kurniawan (2010) yang menunjukkan bahwa usahatani jagung belum mencapai efisiensi ekonomi, karena rata-rata tingkat efisiensi hanya 0,56 yang berarti belum efisien dan petani belum mampu mengatur biaya produksi secara optimal. 
Tabel 5. Sebaran efisiensi ekonomi usahatani jagung anggota dan non-anggota kelompok tani di Kecamatan Marga Tiga tahun 2019

\begin{tabular}{|c|c|c|c|c|c|}
\hline \multirow[b]{2}{*}{$\begin{array}{l}\text { Efisiensi } \\
\text { Ekonomi }\end{array}$} & \multicolumn{2}{|c|}{ Anggota KT } & \multicolumn{2}{|c|}{ Non-anggota KT } & \multirow[b]{2}{*}{ Ket } \\
\hline & $\begin{array}{c}\text { Jumlah } \\
\text { (Org) }\end{array}$ & $\begin{array}{c}\text { Persen } \\
(\%)\end{array}$ & $\begin{array}{c}\text { Jumlah } \\
\text { (Org) }\end{array}$ & $\begin{array}{c}\text { Persen } \\
(\%)\end{array}$ & \\
\hline$<0,70$ & 2,00 & 3,08 & 0,00 & 0,00 & $\begin{array}{l}\text { Belum } \\
\text { efisien }\end{array}$ \\
\hline $0,70-90$ & 26,00 & 40,00 & 14,00 & 26,42 & $\begin{array}{l}\text { Cukup } \\
\text { Efisien }\end{array}$ \\
\hline$>90$ & 37,00 & 56,92 & 39,00 & 73,58 & $\begin{array}{l}\text { Sangat } \\
\text { Efisien }\end{array}$ \\
\hline Jumlah & 65,00 & 100,00 & 53,00 & 100,00 & \\
\hline Rata-rata & 0,89 & & 0,90 & & \\
\hline Minimum & 0,45 & & 0,78 & & \\
\hline Maksimum & 0,98 & & 0,95 & & \\
\hline
\end{tabular}

\section{KESIMPULAN}

Usahatani jagung anggota dan non-anggota kelompok tani sangat efisien secara teknis dengan rata-rata tingkat efisiensi 0,95 yang berarti petani jagung anggota dan non-anggota kelompok tani telah mencapai 95 persen produktivitas potensialnya. Faktor jumlah anggota keluarga dapat meningkatkan inefisiensi teknis, umur dan pengalaman dapat menurunkan inefisiensi teknis, sedangkan pendidikan dan keanggotaan kelompok tani tidak berpengaruh nyata terhadap inefisiensi teknis yang terjadi pada usahatani jagung di Kecamatan Marga Tiga. Usahatani jagung anggota dan non-anggota kelompok tani juga efisien secara ekonomi dengan tingkat efisiensi anggota kelompok tani 0,89 dan non-anggota 0,90 artinya petani jagung baik anggota maupun non-anggota kelompok tani sudah mencapai keuntungan maksimum dan telah mampu mengatur penggunaan faktor produksi dengan cukup optimal.

\section{DAFTAR PUSTAKA}

BPS [Badan Pusat Statistik]. 2018. Buletin Statistik Perdagangan Luar Negeri Ekspor Menurut Kelompok Komoditi dan Negara Maret 2018. Badan Pusat Statistik. Jakarta.

BPS [Badan Pusat Statistik] Kabupaten Lampung Timur. 2018 ${ }^{\mathrm{a}}$. Kabupaten Lampung Timur dalam Angka. BPS Kabupaten Lampung Timur. Lampung Timur.

2018 ${ }^{\mathrm{b}}$. Kecamatan Marga Tiga dalam Angka. BPS Kabupaten Lampung Timur. Lampung Timur.

BPS [Badan Pusat Statistik] Provinsi Lampung. 2018. Provinsi Lampung dalam Angka. BPS Provinsi Lampung. Bandar Lampung.
BPP [Balai Penyuluhan Pertanian] Kecamatan Marga Tiga. 2018. Data Penyuluh Pertanian Kecamatan Marga Tiga. BPP Kecamatan Marga Tiga. Marga Tiga.

Coeli T dan GE Battese. 1998. An Introduction to Efficiency and Productivity Analysis. Kluwer Academic Publishers. Boston.

Edwin Y. 2015. Negara dengan Pertanian Terbaik di Dunia. http://m.kaskus.co.id. [03 November 2018].

Ismail HF. 2018. Statistika untuk Penelitian Pendidikan dan Ilmu-Ilmu Sosial. Prenadamedia Group. Jakarta.

Kurniawan AY. 2010. Analisis efisiensi ekonomi dan daya saing usahatani jagung pada lahan kering di Kabupaten Tanah Laut Kalimantan Selatan. Jurnal Agroscientiae, 17 (1) : 1-17. https://www.academia.edu/4300162/AnalisisE fisiensiEkonomi_Usahatani_Jagung_Lahan_K ering_di_Kalimantan_Selatan_Pendekatan_Fu ngsi_Produksi_Stochastic_Frontier. [17 Juli 2019].

Muhaimin AW. 2012. Analisis teknis faktor produksi padi (Oryza sativa) organik di Desa Sumber Pasir, Kecamatan Pakis, Kabupaten Malang. Jurnal AGRISE, 12 (3) : 193-198. https://agrise.ub.ac.id/index.php/ agrise/article/view/92. [6 April 2019].

Noer SR, Zakaria WA, dan Murniati K. 2018. Analisis efisiensi produksi usahatani padi ladang di Kecamatan Sidomulyo Kabupaten Lampung Selatan. Jurnal Ilmu Ilmu Agribisnis, $6 \quad$ (1) : 1724http://jurnal.fp.unila.ac.id/index.php/JIA/art icle/view/2492. [11 Juli 2019].

Nuryanti S dan Swastika DK. 2011. Peran kelompok tani dalam penerapan teknologi pertanian. Forum Penelitian Agro Ekonomi, 29 (2): 115-128. http://ejurnal.litbang.pertanian.go.id/index.ph p/fae/article/view/3896. [14 Agustus 2019].

Putri R, Murdani, dan Fadli. 2015. Analisis efisiensi teknis pada usahatani kedelai di Kecamatan Peudada Kabupaten Bireuen, Aceh. Jurnal Agrium, 12 (1) : 16-22 http://ojs.unimal.ac.id/index.php/agrium/articl e/view/381. [06 April 2019].

Rofiqoh L, Agustina T, dan Hartadi R. 2018. Analisis efisiensi pengunaan faktor-faktor produksi usahatani semangka di Desa Mayangan Kecamatan Gumukmas Kabupaten Jember. Jurnal Agribest, 2 (1) : 1-13. http://jurnal.unmuhjember.ac.id/index. php/AGRIBEST/article/view/1369. [10 April 2019]. 